\title{
Procedure Agents Group Identifier
}

National Cancer Institute

\section{Source}

National Cancer Institute. Procedure Agents Group Identifier. NCI Thesaurus. Code

C162013.

A character or string that represents a procedure agents group. 